Volume 12 | Number 1| April |2021, Page 42-50/ E-ISSN: 2715-1247 dan P-ISSN: 2087-84xx

\title{
EKONOMI KELUARGA MAHASISWA PROGRAM STUDI PENDIDIKAN ILMU PENGETAHUAN SOSIAL JURUSAN PENDIDIKAN ILMU ILMU SOSIAL FAKULTAS KEGURUAN DAN ILMU PENDIDIKAN
}

\author{
${ }^{1}$ Aminuyati, ${ }^{2}$ Mashudi \\ Program Studi Pendidikan IPS. FKIP Universitas Tanjungpura, Jl. Prof. Dr. H. Hadari Nawawi \\ e-mail: aminuyati@,fkip.untan.ac.id
}

\begin{abstract}
Abstrak: Tujuan penelitian ini adalah untuk mengetahui kondisi ekonomi keluarga mahasiswa prodi pendidikan IPS FKIP Untan. Bentuk penelitian adalah survey. Hasil penelitian kondisi keluarga sebagian besar berasal dari daerah luar kota Pontianak, sebanyak 139 orang mahasiswa $(67,48 \%)$ dan dari kota Pontianak sebanyak 67 orang $(32,52 \%)$. Profesi orang tua sebagian besar petani. Dengan rata-rata penghasilan keluarga mahasiswa berada pada rentang Rp $1.000 .000-\mathrm{Rp}$ 1.950.000 (penghasilan ayah, ibu, saya dan saudara). Penghasilan yang di peroleh tidak mencukupi kebutuhan keluarga, karena rata-rata pengeluaran perbulan di atas Rp 2.000.000. Pada umumnya orang tua mahasiswa mengeluh karena beban ekonomi keluarga cukup berat. Guna membantu ekonomi keluarga, sebagian besar mahasiswa turut bekerja untuk membantu ekonomi keluarga. Seperti: bekerja jaga toko sembako, mengantar anak-anak kesekolah, sebagai pinatu (menyeterika pakaian) pada usaha luandry. Status rumah yang dimiliki mahasiswa adalah rumah hak milik pribadi. Fasilitas penerangan menggunakan listrik dengan daya 450 watt. Sarana hiburan televise, tape recorder dan radio. Pembayaran rekening listrik pernah menunggak. Ada 42 mahasiswa yang mendapat beasiswa bidik misi, 4 mahasiswa yang mendapat beasiswa Pemda Kabupaten Kayong. 1 mahasiswa yang mendapat beasiswa Pemda Kabupaten Sekadau, 1 mahasiswa mendapat beasiswa Untan Mandiri Parsial. 10 mahasiswa yang mendapat beasiswa PPA dan 8 mahasiswa yang mendapat beasiswa PBM. Pembayaran uang kuliah mahasiswa pada rentang UKT 3, 4 dan 5. Di Pontianak tinggal dirumah orang sebagai asisten rumah tangga, dan tidak dibayar uang kuliah hanya diberi kesempatan untuk tempat tinggal dan makan. Sedangkan uang kuliah harus bayar sendiri.
\end{abstract}

Kata Kunci : Ekonomi, Keluarga

\begin{abstract}
The purpose of this study was to determine the economic condition of the families of students of the Social Sciences Education Study Program, FKIP Untan. The form of research is a survey. The results of the research on family conditions mostly came from areas outside the city of Pontianak, as many as 139 students (67.48\%) and from the city of Pontianak as many as 67 people $(32.52 \%)$. Parents are mostly farmers. With an average student family income in the range of Rp. 1,000,000 - Rp. 1,950,000 (income of father, mother, me and siblings). The income earned is not sufficient for the family's needs, because the average monthly expenditure is over Rp. 2,000,000. In general, parents of students complained that the family's economic burden was quite heavy. In order to help the family economy, most students also work to help the family economy. Such as: guarding a grocery store, taking children to school, as a pinatu (ironing clothes) in a luandry business. The status of the house owned by students is a house that is privately owned. The lighting facility uses electricity with a power of 450 watts. Entertainment facilities for television, tape recorder and radio. Electricity bill payments have been in arrears. There are 42 students who received Bidik Misi scholarships, 4 students received scholarships from the local government of Kayong Regency. 1 student who gets a scholarship from the Sekadau Regency Government, 1 student gets a Partial Independent Untan scholarship. 10 students who received PPA scholarships and 8 students who received PBM scholarships. Payment of student tuition fees ranges from UKT 3, 4 and 5. In Pontianak living at someone's house as a household assistant, and not being paid tuition fees, they are only given the opportunity to live and eat. Meanwhile, tuition fees must be paid by themselves.
\end{abstract}

Keywords: Family, Economy 
Volume 12 | Number 1| April |2021, Page 42-50/ E-ISSN: 2715-1247 dan P-ISSN: 2087-84xx

\section{PENDAHULUAN}

Ekonomi merupakan titik pusat dari segala ilmu sosial dan merupakan ilmu yang tertua dari sastra serta yang terbaru dari ilmu pengetahuan. Jadi berbicara ekonomi tidak terlepas dengan ilmu ekonomi. Yang membahas bagaimana usaha manusia dalam memenuhi kebutuhan dengan menggunakan sumber-sumber produktif yang langka sehingga dapat memenuhi kebutuhan manusia berupa barang dan jasa serta membagikannya untuk dikonsumsi, baik untuk waktu sekarang maupun masa yang akan datang. Untuk itu perlu tindakan ekonomi yang artinya berbuat sesuatu untuk mencegah pemborosan. Sehingga setiap besaran biaya-biaya yang dikeluarkan perlu dimanag. Sejalan dengan pendapat Rosyidi (2011) mengatakan ekonomi merupakan cabang ilmu pengetahuan yang berdaya upaya memberikan pengetahuan dan pengertian tentang gejala-gejala masyarakat yang timbul karena perbuatan manusia dalam usahanya untuk memenuhi kebutuhan untuk mencapai kemakmuran.

Masa depan anak-anak dapat diwujud nyatakan melalui dunia pendidikan. Sehingga ada pendewasaan dalam hal pengetahuan, kepribadian dan ketrampilan. Sejalan pendapat Aminuyati (2018) setiap anak-anak dapat dirubah pengetahuan, kepribadian dan ketrampilan melalui dunia pendidikan sesuai jenjang pendidikan". Untuk mencapai cita-cita tersebut tidak terlepas dari kondisi sosial ekonomi keluarga. Dengan asumsi orang tua yang status sosial ekonominya menengah keatas lebih memperhatikan pendidikan bagi putra-putrinya demi masa depan. Sedangkan orang tua yang kondisi sosial ekonominya rendah kurang memikirkan pendidikan bagi putra-purtinya karena keinginan ada sementara kondisi sosial ekonomi kurang mendukung. Jadi hanya berangan-angan saja. Sejalan pendapat Sismons yang dikutip Nopianti (2015) latar belakang keluarga biasanya berkaitan dengan status sosial ekonomi keluarga. Sedangkan status sosial ekonomi menggunakan indikator pendidikan, pekerjaan dan penghasilan orang tua. Orang tua berpendapatan menengah dan tinggi lebih sering memikirkan pendidikan sebagai suatu yang harus didorong oleh orang tua dan guru. Sebaliknya orang tua berpendapatan rendah lebih cenderung memandang pendidikan sebagai tugas guru. Karena system keterkaitan sekolah dan keluarga dapat memberikan keuntungan kepada peserta didik yang orang tua berpendapatan rendah.

Membangkitkan motivasi belajar bagi setiap peserta didik sesuai jenjang pendidikan, dapat didukung jika tersedianya kendisi sosial ekonomi keluarga yang memadai. Kondisi sosial ekonomi keluarga merupakan komponen yang penting dan sangat besar mamfaatnya dalam mendukung mahasiswa menyelesaikan pendidikan. Kondisi sosial ekonomi yang tersedia dan dimanfatkan secara optimal akan membantu mahasiswa untuk memperoleh berbagai pengetahuan, merubah kepribadian dan meningkatkan ketrampilan untuk memungkinkan mahasiswa dapat belajar dengan baik dan memperoleh nilai yang memuaskan sehingga mendukung mahasiswa masuk dunia kerja.

Sedangkan ekonomi keluarga merupakan posisi keluarga dalam kelompok masyarakat yang ditentukan melalui kondisi pendapatan, pengeluaran dan kemampuan dalam memenuhi kebutuhan hidup baik kebutuhan rohani maupun kebutuhan jasmani. Ekonomi keluarga adalah suatu kajian tentang upaya manusia dalam memenuhi kebutuhan-kebutuhannya melalui aktivitas-aktivitas yang dilakukan oleh seseorang yang bertanggungjawab atas kebutuhan dan kebahagiaan bagi kehidupannya (sekelompok komunitas dari masyarakatnya). (http://www.wartamadrasahku.com/, diakses tanggal 12 Juni 2018). Jadi ekonomi keluarga merupakan suatu situasi setiap keluarga untuk mengelola keuangan berdasarkan pendapatan masing-masing keluarga sesuai profesi yang ditekuni dan latar belakang pendidikan yang dimiliki, untuk memenuhi kebutuhan setiap hari. Orang tua bertanggungjawab sebagai pelindung, pendidik dan pelakau hubungan sosial dalam keluarga demi masa depan anakanak, terpenuhi setiap kebutuhan keluarga setiap hari. Yaitu tersedianya sandang, pangan, pendidikan dan kesehatan keluarga. Aminuyati (2018) orang tua/keluarga merupakan unit satuan masyarakat yang terkecil yang sekaligus merupakan suatu kelompok kecil dalam masyarakat.

Motivasi anak-anak untuk bersekolah diantaranya akan dipengaruhi pendapatan orang tua melalui profesi masing-masing. Dengan adanya pendapatan, harapannya orang tua dapat 
Volume 12 | Number 1| April |2021, Page 42-50/ E-ISSN: 2715-1247 dan P-ISSN: 2087-84xx

mempergunakan untuk memenuhuhi kebutuhan pokok, kebutuhan sekunder dan biaya pendidikan anak-anak. Sejalan pendapat Sukirno (2013) mengatakan pendapatan adalah semua hasil diperoleh yang dapat dipergunakan oleh penerimanya untuk membeli barangbarang dan jasa-jasa yang mereka butuhkan dan mereka inginkan". Pendapatan masyarakat bersumber dari usaha sendiri, hasil berdagang, bertani, berkerja sebagai penggaraf dan bekerja sebagai pegawai/karyawan. Sejalan pendapat T.Gilarso (2002) pendapatan "bersumber dari swadaya atau usaha sendiri seperti pengerjaan sawah, hasil milik sendiri dan bekerja pada orang lain" menurut Winardi (1990) pendapatann "hasil berupa uang diperoleh dari material yang dicapai dari penggunaan atas jasa-jasa manusia bebas" selanjutnya Haryono Yusuf (2004) pendapatan merupakan "jumlah berapa nilai nominal rupiah yang dihasilkan melalui penjualan setelah dikurangi harga pokok penjualan dan biaya". Jadi pendapatan merupakan semua penghasilan yang diterima oleh seseorang dalam jangka waktu tertentu misalkan satu minggu, satu bulan dan satu tahun tergantung pada jenis pekerjaan atau profesi yang dimiliki orang tersebut. Pendapatan dapat diperoleh, jika masyarakat memiliki profesi kerja, melihat, menggali dan mengkaji peluangpeluang yang memungkinkan untuk dapat dihasilkan dengan memanfaatkan sumber daya yang tersedia dilingkungan dimana masyarakat berdomisili. Pendapatan dapat diperoleh, jika masyarakat memiliki profesi, melihat, menggali dan mengkaji peluang-peluang yang memungkinkan untuk dapat dihasilkan dengan memanfaatkan sumber daya alam yang tersedia dilingkungan dimana masyarakat berdomisili. Dengan pendapatan maka keadaan ekonomi keluarga dapat memenuhi kebutuhan pokok keluarga, sehingga tidak menutup kemungkinan motivasi orang tua untuk menyekolahkan anakanaknya lebih besar, tetapi sebaliknya jika kondisi ekonomi keluarga sulit untuk memenuhi kebutuhan pokok, maka tidak menutup kemungkinan akan berdampak pada kurangnya motivasi orang tua untuk menyekolahkan anak-anaknya kejenjang pendidikan yang lebih tinggi. Sejalan pendapat Layli dan Pristyadi (2013) mengatakan "menentukan berapa besar kecilnya pengeluaran konsumsi keluarga di dasarkan pada besar kecilnya tingkat pendapatan masyarakat" Pendapatan merupakan dasar dari kehidupan suatu keluarga. Jika pendapatan besar maka kualitas dan taraf hidup akan semakin tinggi. Sejumlah kebutuhan kehidupan yang telah terpuaskan merupakan pola konsumsi yang tercapai. Besaran pengeluaran keluarga dapat dilihat dari berapa pendapatan yang diperoleh. Tingkat pendapatan yang berbeda-beda pada setiap keluarga akan menentukan kondisi ekonomi keluarga.

Penelitian ini, mengkaji ekonomi keluarga mahasiswa Program Studi Pendidikan Ilmu Pengetahuan Sosial Fakultas Keguruan Dan Pendidikan Universitas Tanjungpura Pontianak. Seperti: kondisi keluarga, kondisi ekonomi keluarga, kondisi rumah dan biaya kuliah mahasiswa. Berdasarkan data mahasiswa Program Studi PIPS sebagian besar berasal dari daerah (luar kota Pontianak) sebanyak 139 orang mahasiswa $(67,48 \%)$ dan dari kota Pontianak sebanyak 67 orang $(32,52 \%)$. Profesi orang tua sebagai petani 105 orang (51\% mahasiswa) dari 206 , pedagang 16 orang (8\%) dari 206, nelayan 23 orang (11\%) dari 206 dan ASN 19 orang (9\%), buruh 16 orang (8\%) dari 206 dan karyawan 27 orang (13\%). Dari tahun 2014 sampai tahun 2018 ada 3 orang mahasiswa yang tidak melanjutkan kuliah karena kondisi ekonomi keluarga yang kurang mendukung. Ada 5 mahasiswa yang minta rekomendasi dispensasi untuk pembayaran uang daftar ulang yang tertunda. Ada 42 mahasiswa yang mendapat beasiswa bidik misi, 4 mahasiswa yang mendapat beasiswa Pemda Kabupaten Kayong. 1 mahasiswa yang mendapat beasiswa Pemda Kabupaten Sekadau, 1 mahasiswa mendapat beasiswa Untan Mandiri Parsial. 10 mahasiswa yang mendapat beasiswa PPA dan 8 mahasiswa yang mendapat beasiswa PBM. Berdasarkan permasalahan tersebut maka penulis tertarik untuk melakukan penelitian berhubungan dengan ekonomi keluarga mahasiswa Program Studi PIPS.

\section{METODE}

Metode yang digunakan dalam penelitian ini adalah metode deskriptif yang menggambarkan secara fakta dan objektif mengenai kondisi ekonomi keluarga mahasiswa Program Studi Pendidikan Ilmu Pengetahuan Sosial Jurusan Pendidikan Ilmu Ilmu Sosial dalam aspek sebagaimana adanya pada saat sekarang. Berdasarkan rumusan masalah dan tujuan, maka penelitian yang dilaksanakan 
Volume 12 | Number 1| April |2021, Page 42-50/ E-ISSN: 2715-1247 dan P-ISSN: 2087-84xx

dipandang sesuai adalah penelitian deskriptif kualitatif yaitu tipe penelitian yang bertujuan untuk mendeskripsikan keadaan subjek dan objek penelitian apa adanya. Bentuk penelitian adalah bentuk survey, sejalan pendapat Sugiono (2017) bentuk survey "digunakan untuk melakukan penarikan kesimpulan-kesimpulan secara umum (generalisasi) dari sampel yang ditentukan". Bentuk survey dengan menyebarkan angket kepada mahasiswa guna mengukur ekonomi keluarga mahasiswa Program Studi Pendidikan Ilmu Pengetahuan Sosial Jurusan Pendidikan Ilmu Ilmu Sosial Fakultas Keguruan dan Ilmu Pendidikan Universitas Tanjungpura Pontianak. Populasi menurut Suharsimi Arikunto (2013) adalah "keseluruhan subjek penelitian" Populasi dalam penelitian ini adalah mahasiswa Program Studi Pendidikan Ilmu Pengetahuan Sosial FKIP Untan Pontianak yang berjumlah 206 orang mahasiswa. Penentuan sampel dalam penelitian ini berjumlah $20 \%$ x 206 orang mahasiswa $=41,20$ orang mahasiswa menjadi 41 mahasiswa. Di lakukan secara acak pada setiap angkatan. Teknik pengumpul data di lakukan dengan melakukan wawancara dengan orang tua mahasiswa dan menyebarkan angket kepada mahasiswa Program Studi PIPS Jurusan Pendidikan Ilmu Ilmu Sosial guna menggali berbagai informasi yang di perlukan dalam penelitian ini. Analisis data di lakukan melalui pendekatan kuanlitatif. Data dari hasil wawancara di analisis secara deskriptif kualitatif, ditarik kesimpulan dan di sajikan dalam penelitian. Sedangkan pendekatan selanjutnya di lakukan langkah-langkah:
1. Melakukan survey dan menyebarkan angket kepada mahasiswa sebanyak 49 mahasiswa

2. Instrumen divalidasi dengan pertimbangan pakar dan praktisi, dilakukan guna uji coba sebagai langkah umpan balik.

3. Hasil pengukuran dilakukan sebagai pemetaan hasil penelitian tentang kondisi ekonomi keluarga mahasiswa Program Studi PIPS Jurusan PIIS

4. Seluruh data yang dilakukan melalui penyebaran angket dan bantuan wawancara ditempuh menggunakan rumus persentase. Rumus yang dikemukakan Mardalis (2014):

$\mathrm{P}=\mathrm{F} / \mathrm{Y} \times 100 \%$

Dimana:

$\mathrm{P}=$ Persentase

$\mathrm{F}=$ Frekuensi yang sedang dicari persentasenya (frekuensi jawaban)

$\mathrm{Y}=$ Jumlah responden

Analisis data menggunakan skala likert berhubungan dengan pernyataan sikap misalkan sangat baik (skor 5), baik (skor 4), cukup baik (skor 3), kurang baik (skor 2) dan sangat kurang baik (skor 1). Hasil data diperoleh di analisis dengan menghitung rata-rata jawaban berdasarkan skor setiap jawaban:

Nilai skor tertinggi $(\mathrm{Y})=$ responden $\mathrm{x}$ jawaban alternative jawaban tertinggi

Nilai skor terendah $(X)=$ responden $x$ jawaban alternative jawaban terendah Rentang skor $=$ nilai total skor $/ Y$ x 100 Selanjutnya mengukur skor jawaban angket diperoleh rentang skor dengan cara kontinum ke dalam lima kategori:

Tabel 3.1 rentang skor dan kriteria penilaian

\begin{tabular}{|c|c|}
\hline Krietria penilaian & Rentang skor \\
\hline Sangat baik & $80 \%-100 \%$ \\
\hline Baik & $60 \%-79,99 \%$ \\
\hline Cukup baik & $40 \%-59,99 \%$ \\
\hline Tidak baik & $20 \%-39,99 \%$ \\
\hline Sangat tidak baik & $0 \%-19,99 \%$ \\
\hline
\end{tabular}

HASIL DAN PEMBAHASAN

Kondisi keluarga mahasiswa Program Studi PIPS Jurusan PIIS FKIP Untan

Kondisi keluarga mahasiswa Program Studi Pendidikan Ilmu Pengetahuan Sosial Jurusan PIIS Fakultas Keguruan Dan Pendidikan Universitas Tanjungpura Pontianak. Berdasarkan data mahasiswa
Program Studi PIPS sebagian besar berasal dari daerah (luar kota Pontianak) sebanyak 139 orang mahasiswa $(67,48 \%)$ dan dari kota Pontianak sebanyak 67 orang $(32,52 \%)$. Sebagian besar keluarga mahasiswa dari struktur keluarga utuh (ayah dan ibu masih lengkap). Pendidikan ayah sebagian besar tamat jenjang pendidikan menengah atas dan 
pendidikan ibu sebagian besar tamat jenjang pendidikan dasar. Profesi orang tua sebagai petani 105 orang (51\% mahasiswa) dari 206 , pedagang 16 orang (8\%) dari 206, nelayan 23 orang $(11 \%)$ dari 206 dan ASN 19 orang $(9 \%)$, buruh 16 orang (8\%) dari 206 dan karyawan 27 orang (13\%).

\section{Kondisi ekonomi keluarga mahasiswa Program Studi PIPS Jurusan PIIS FKIP Universitas Tanjungpura Pontianak}

Kondisi ekonomi keluarga mahasiswa Program Studi PIPS Jurusan PIIS FKIP Universitas Tanjungpura Pontianak. Penghasilan ayah perbulan sebagian besar ratarata pada rentang $\mathrm{Rp} 1.000 .000$ - Rp 1.950.000. Sementara ibu sebagian besar tidak memiliki penghasilan. Sebagian besar rata-rata penghasilan keluarga mahasiswa berada pada rentang $\mathrm{Rp} \quad 1.000 .000$ - $\mathrm{Rp} \quad 1.950 .000$ (penghasilan ayah, ibu, saya dan saudara). Penghasilan yang di peroleh tidak mencukupi kebutuhan keluarga, karena rata-rata pengeluaran perbulan di atas Rp 2.000.000. Pada umumnya orang tua mahasiswa mengeluh karena beban ekonomi keluarga cukup berat. Guna membantu ekonomi keluarga, sebagian besar mahasiswa turut bekerja untuk membantu ekonomi keluarga. Seperti bekerja jaga toko sembako, mengantar anak-anak kesekolah, sebagai pinatu (menyeterika pakaian) pada usaha laundry.

Kondisi rumah mahasiswa Program Studi PIPS Jurusan PIIS FKIP Universitas Tanjungpura Pontianak

Kondisi rumah mahasiswa Program Studi PIPS Jurusan PIIS FKIP Universitas Tanjungpura Pontianak. Sebagian besar status rumah yang dimiliki mahasisawa adalah rumah hak milik pribadi. Fasilitas penerangan menggunakan listrik dengan daya 450 watt. Sarana hiburan televise, tape recorder dan radio. Pembayaran rekening listrik pernah menunggak.

Biaya kuliah mahasiswa Program Studi PIPS Jurusan PIIS FKIP Universitas Tanjungpura Pontianak

Biaya kuliah mahasiswa Program Studi PIPS Jurusan PIIS FKIP Universitas Tanjungpura Pontianak dari tahun 2014 sampai tahun 2018 ada 3 orang mahasiswa yang tidak melanjutkan kuliah karena kondisi ekonomi keluarga yang kurang mendukung. Ada 5 mahasiswa yang minta rekomendasi dispensasi untuk pembayaran uang daftar ulang yang tertunda. Ada 42 mahasiswa yang mendapat beasiswa bidik misi, 4 mahasiswa yang mendapat beasiswa Pemda Kabupaten Kayong. 1 mahasiswa yang mendapat beasiswa Pemda Kabupaten Sekadau, 1 mahasiswa mendapat beasiswa Untan Mandiri Parsial. 10 mahasiswa yang mendapat beasiswa PPA dan 8 mahasiswa yang mendapat beasiswa PBM. Sebagian besar pembayaran uang kuliah mahasiswa pada rentang UKT 3, 4 dan 5. Motivasi belajar mahasiswa program studi PIPS FKIP Untan cukup tinggi dari hasil wawancara dengan beberapa mahasiswa dan kondisi hasil belajar yang diperoleh dari indek prestasi komulatif yang didapat. Keinginan mahasiswa untuk menyelesaikan pendidikan tepat waktu cukup tinggi hampir $87 \%$ (180 orang mahasiswa) dari 206 mahasiswa program studi PIPS berupaya segera menyelesaikan pendidikan. Hanya 13\% (26 orang mahasiswa) yang menjawab terkendala karena faktor biaya secara khusus yang menyangkut Uang Kuliah Tunggal (UKT) yaitu UKT 4 dan 5 yang tidak bisa diturunkan ke UKT 1, 2 dan 3 Sementara profesi orang tua sebagian besar petani penyadap karet. Di Pontianak tinggal dirumah orang sebagai asisten rumah tangga, dan tidak dibayar uang kuliah hanya diberi kesempatan untuk tempat tinggal dan makan. Sedangkan uang kuliah harus bayar sendiri. Walaupun demikian mahasiswa tetap termotivasi untuk menyelesaikan pendidikan.Sedangkan untuk mendapatkan beasiswa harus bersaing secara kompetitif karena yang terpilih tentu saja memiliki nilai indek prestasi komulatif yang tinggi.

Tahun akademik 2019 periode wisuda kedua Program Studi PIPS meluluskan mahasiswa berprestasi tercepat (3 tahun 3 bulan 20 hari), Predikat Kelulusan Dengan Pujian (IPK 3,89) dan Peringkat Pertama atas nama mahasiswa Eko Suprayitno. NIM. F 1261151022. Tahun akademik 2019 periode wisuda ketiga Program Studi PIPS meluluskan wisudawan termuda (20 tahun 8 bulan 3 hari) atas nama Krisma Haryuniati. NIM. F 1261151015. Saat ini ada 3 mahasiswa alumni PIPS FKIP Untan yang sedang melanjutkan S2 PIPS di Universitas Negeri Yogyakarta. 
Ekonomi keluarga mahasiswa Program Studi PIPS Jurusan PIIS FKIP Universitas Tanjungpura, dapat dideskripsikan sebagai berikut:

\begin{tabular}{|c|c|c|c|c|c|c|c|}
\hline \multirow[t]{2}{*}{ No } & \multirow[t]{2}{*}{ Indikator } & \multirow{2}{*}{$\begin{array}{l}\text { Kisi-kisi } \\
\text { angket }\end{array}$} & \multicolumn{5}{|c|}{ Kategori penilaian } \\
\hline & & & SS & $\mathrm{S}$ & $\mathrm{CS}$ & $\mathrm{TS}$ & STS \\
\hline \multirow[t]{2}{*}{1} & Kondisi keluarga & $1-21$ & 16 & 16 & 16 & 19 & 18 \\
\hline & \multicolumn{2}{|l|}{ Total persentase (\%) } & 76,19 & 76,19 & 76,19 & 90,47 & 85,71 \\
\hline \multirow[t]{2}{*}{2} & Ekonomi keluarga & $22-33$ & 3 & 6 & 8 & 7 & 8 \\
\hline & \multicolumn{2}{|l|}{ Total persentase $(\%)$} & 25 & 50 & 66,66 & 58,33 & 66,66 \\
\hline \multirow[t]{2}{*}{3} & Keadaan rumah & $32-43$ & 6 & 7 & 6 & 7 & 7 \\
\hline & \multicolumn{2}{|l|}{ Total persentase $(\%)$} & 50 & $\mathbf{5 8 , 3 3}$ & 50 & $\mathbf{5 8 , 3 3}$ & $\mathbf{5 8 , 3 3}$ \\
\hline \multirow[t]{2}{*}{4} & Biaya kuliah & $44-55$ & 7 & 8 & 10 & 7 & 7 \\
\hline & \multicolumn{2}{|l|}{ Total persentase (\%) } & $\mathbf{5 8 , 3 3}$ & 88,88 & 83,33 & 58,33 & 58,33 \\
\hline
\end{tabular}

\section{Kondisi keluarga mahasiswa Program Studi PIPS Jurusan PIIS FKIP Untan}

Kondisi keluarga mahasiswa Program Studi Pendidikan Ilmu Pengetahuan Sosial Jurusan PIIS Fakultas Keguruan Dan Pendidikan Universitas Tanjungpura Pontianak. Berdasarkan data mahasiswa Program Studi PIPS sebagian besar berasal dari daerah (luar kota Pontianak) sebanyak 139 orang mahasiswa $(67,48 \%)$ dan dari kota Pontianak sebanyak 67 orang $(32,52 \%)$. Sebagian besar keluarga mahasiswa dari struktur keluarga utuh (ayah dan ibu masih lengkap) terlihat dari jawaban mahasiswa 16 (76,19\%). Pendidikan ayah sebagian besar tamat jenjang pendidikan menengah atas terlihat dari jawaban mahasiswa 19 (90,47\%) dan pendidikan ibu sebagian besar tamat jenjang pendidikan dasar dari jawaban mahasiswa $18(85,71 \%)$. Profesi orang tua sebagai petani 105 orang (51\% mahasiswa) dari 206, pedagang 16 orang (8\%) dari 206, nelayan 23 orang (11\%) dari 206 dan ASN 19 orang $(9 \%)$, buruh 16 orang (8\%) dari 206 dan karyawan 27 orang (13\%).

Kondisi ekonomi keluarga mahasiswa Program Studi PIPS Jurusan PIIS FKIP Universitas Tanjungpura Pontianak

Kondisi ekonomi keluarga mahasiswa Program Studi PIPS Jurusan PIIS FKIP Universitas Tanjungpura Pontianak. Dari jawaban mahasiswa $8(66,66 \%)$ penghasilan ayah perbulan sebagian besar rata-rata pada rentang Rp 1.000.000 - Rp 1.950.000. Dari jawaban mahasiswa $6(50 \%)$ sebagian besar ibu mahasiswa tidak memiliki penghasilan.
Sebagian besar mahasiswa menjawab 7 $(58,33 \%)$ rata-rata penghasilan keluarga mahasiswa berada pada rentang $\mathrm{Rp} 1.000 .000$ - Rp 1.950.000 (penghasilan ayah, ibu, saya dan saudara). Penghasilan yang di peroleh tidak mencukupi kebutuhan keluarga, karena ratarata pengeluaran perbulan di atas $\mathrm{Rp} 2.000 .000$. Pada umumnya orang tua mahasiswa mengeluh karena beban ekonomi keluarga cukup berat. Guna membantu ekonomi keluarga, sebagian besar mahasiswa turut bekerja untuk membantu ekonomi keluarga. Seperti bekerja jaga toko sembako, mengantar anak-anak kesekolah, sebagai pinatu (menyeterika pakaian) pada usaha laundry.

Kondisi rumah mahasiswa Program Studi PIPS Jurusan PIIS FKIP Universitas Tanjungpura Pontianak

Kondisi rumah mahasiswa Program Studi PIPS Jurusan PIIS FKIP Universitas Tanjungpura Pontianak. Sebagian besar 6 mahasiswa (50\%) menjawab status rumah yang dimiliki mahasiswa adalah rumah hak milik pribadi. 7 mahasiswa (58.33\%) menjawab Fasilitas penerangan menggunakan listrik dengan daya 450 watt. Sarana hiburan televise, tape recorder dan radio. Pembayaran rekening listrik pernah menunggak.

Biaya kuliah mahasiswa Program Studi PIPS Jurusan PIIS FKIP Universitas Tanjungpura Pontianak

Biaya kuliah mahasiswa Program Studi PIPS Jurusan PIIS FKIP Universitas Tanjungpura Pontianak dari tahun 2014 sampai tahun 2018 ada 3 orang mahasiswa yang tidak melanjutkan kuliah karena kondisi ekonomi 
Volume 12 | Number 1| April |2021, Page 42-50/ E-ISSN: 2715-1247 dan P-ISSN: 2087-84xx

keluarga yang kurang mendukung. Ada 5 mahasiswa yang minta rekomendasi dispensasi untuk pembayaran uang daftar ulang yang tertunda. Ada 42 mahasiswa yang mendapat beasiswa bidik misi, 4 mahasiswa yang mendapat beasiswa Pemda Kabupaten Kayong. 1 mahasiswa yang mendapat beasiswa Pemda Kabupaten Sekadau, 1 mahasiswa mendapat beasiswa Untan Mandiri Parsial. 10 mahasiswa yang mendapat beasiswa PPA dan 8 mahasiswa yang mendapat beasiswa PBM. Sebagian besar pembayaran uang kuliah mahasiswa pada rentang UKT 3, 4 dan 5. Motivasi belajar mahasiswa program studi PIPS FKIP Untan cukup tinggi dari hasil wawancara dengan beberapa mahasiswa dan kondisi hasil belajar yang diperoleh dari indek prestasi komulatif yang didapat. Keinginan mahasiswa untuk menyelesaikan pendidikan tepat waktu cukup tinggi hampir $87 \%$ (180 orang mahasiswa) dari 206 mahasiswa program studi PIPS berupaya segera menyelesaikan pendidikan. Hanya 13\% (26 orang mahasiswa) yang menjawab terkendala karena faktor biaya secara khusus yang menyangkut Uang Kuliah Tunggal (UKT) yaitu UKT 4 dan 5 yang tidak bisa diturunkan ke UKT 1, 2 dan 3 Sementara profesi orang tua sebagian besar petani penyadap karet. Mahasiswa menjawab 8 (88.88\%) bahwa uang kuliah tunggal berada pada UKT 4 dan 5. Di Pontianak tinggal dirumah orang sebagai asisten rumah tangga, dan tidak dibayar uang kuliah hanya diberi kesempatan untuk tempat tinggal dan makan. Sedangkan uang kuliah harus bayar sendiri. Walaupun demikian mahasiswa tetap termotivasi untuk menyelesaikan pendidikan.Sedangkan untuk mendapatkan beasiswa harus bersaing secara kompetitif karena yang terpilih tentu saja memiliki nilai indek prestasi komulatif yang tinggi

\section{SIMPULAN DAN SARAN \\ Simpulan}

Dari hasil penelitian dapat disimpulkan sebagai berikut:

Kondisi keluarga mahasiswa Program Studi Pendidikan Ilmu Pengetahuan Sosial Jurusan PIIS Fakultas Keguruan Dan Pendidikan Universitas Tanjungpura Pontianak. Berdasarkan data mahasiswa Program Studi PIPS sebagian besar berasal dari daerah (luar kota Pontianak) sebanyak 139 orang mahasiswa $(67,48 \%)$ dan dari kota Pontianak sebanyak 67 orang $(32,52 \%)$.
Sebagian besar keluarga mahasiswa dari struktur keluarga utuh (ayah dan ibu masih lengkap) terlihat dari jawaban mahasiswa 16 (76,19\%). Pendidikan ayah sebagian besar tamat jenjang pendidikan menengah atas terlihat dari jawaban mahasiswa 19 (90,47\%) dan pendidikan ibu sebagian besar tamat jenjang pendidikan dasar dari jawaban 18 $(85,71 \%)$ mahasiswa. Profesi orang tua sebagai petani 105 orang (51\% mahasiswa) dari 206 , pedagang 16 orang $(8 \%)$ dari 206 , nelayan 23 orang (11\%) dari 206 dan ASN 19 orang (9\%), buruh 16 orang (8\%) dari 206 dan karyawan 27 orang $(13 \%)$.

Kondisi ekonomi keluarga mahasiswa Program Studi PIPS Jurusan PIIS FKIP Universitas Tanjungpura Pontianak. Pada umumnya orang tua mahasiswa mengeluh karena beban ekonomi keluarga cukup berat. Guna membantu ekonomi keluarga, sebagian besar mahasiswa turut bekerja untuk membantu ekonomi keluarga. Seperti: bekerja jaga toko sembako, mengantar anak-anak kesekolah, sebagai pinatu (menyeterika pakaian) pada usaha luandry.

Kondisi rumah mahasiswa Program Studi PIPS Jurusan PIIS FKIP Universitas Tanjungpura Pontianak. Sebagian besar 6 mahasiswa (50\%) menjawab status rumah yang dimiliki mahasiswa adalah rumah hak milik pribadi. 7 mahasiswa (58.33\%) menjawab Fasilitas penerangan menggunakan listrik dengan daya 450 watt. Sarana hiburan televise, tape recorder dan radio. Pembayaran rekening listrik pernah menunggak.

Biaya kuliah mahasiswa Program Studi PIPS Jurusan PIIS FKIP Universitas Tanjungpura Pontianak ada dari beasiswa da nada pula yang membayar secara mandiri, dan dari tahun 2014 sampai tahun 2018 ada 3 orang mahasiswa yang tidak melanjutkan kuliah karena kondisi ekonomi keluarga yang kurang mendukung. Ada 5 mahasiswa yang minta rekomendasi dispensasi untuk pembayaran uang daftar ulang yang tertunda. Keinginan mahasiswa untuk menyelesaikan pendidikan tepat waktu cukup tinggi hampir 87\% (180 orang mahasiswa) dari 206 mahasiswa program studi PIPS berupaya segera menyelesaikan pendidikan. Hanya 13\% (26 orang mahasiswa) yang menjawab terkendala karena faktor biaya secara khusus yang menyangkut Uang Kuliah Tunggal (UKT) yaitu UKT 4 dan 5 yang tidak bisa diturunkan ke UKT 1, 2 dan 3 Sementara 
Volume 12 | Number 1| April |2021, Page 42-50/ E-ISSN: 2715-1247 dan P-ISSN: 2087-84xx

profesi orang tua sebagian besar petani penyadap karet. Mahasiswa menjawab 8 (88.88\%) bahwa uang kuliah tunggal berada pada UKT 4 dan 5. Di Pontianak tinggal dirumah orang sebagai asisten rumah tangga, dan tidak dibayar uang kuliah hanya diberi kesempatan untuk tempat tinggal dan makan. Sedangkan uang kuliah harus bayar sendiri. Walaupun demikian mahasiswa tetap termotivasi untuk menyelesaikan pendidikan.Sedangkan untuk mendapatkan beasiswa harus bersaing secara kompetitif karena yang terpilih tentu saja memiliki nilai indek prestasi komulatif yang tinggi.

\section{Saran}

Saran yang peneliti sampai berdasarkan hasil penelitian:

Perlu diperhatikan dalam penentuan UKT bagi mahasiswa yang melanjutkan pendidikan di Program Studi PIPS secara khusus, karena kurang informasi kepada mahasiswa baru untuk penulisan profesi orang tua/wali yang ada hubungan dengan pendapatan. Sebagai contoh mahasiswa yang kuliah dan tinggal dengan orang tua asuh di Kota Pontianak, padahal mahasiswa sebagai asisten rumah tangga, tidak diberi upah (seleri) hanya diberi kesempatan bertempat tinggal dan makan di rumah orang tua asuh, sedang biaya kuliah bayar sendiri. Sementara mahasiswa menulis dalam format yang diisi profesi orang tua sebagaimana kondisi orang tua/wali tempat tinggal. Yang berprofesi sebagai pegawai/karyawan ASN/karyawan dan memiliki fasilitas kendaraan baik mobil maupun sepeda motor. Begitu juga dengan kondisi rekening listrik. Seharusnya mahasiswa menulis sesuai kondisi orang tua yang sesungguhnya

\section{DAFTAR RUJUKAN}

Aminuyati. (2018). Kerangka Berpikir Ilmu Sosial Dalam Konteks Pendidikan Ilmu Pengetahuan Sosial. Pontianak: Pustaka Rumah Aloy.

Arikunto, Suharsimi. (2014). Prosedur Penelitian Suatu Pendekatan Praktik. Jakarta: Rineka Cipta.

Hamdani. (2011). Strategi Belajar Mengajar.Bandung: CV Pustaka Setia.

Haryono Yusuf (2004). PengantarAkuntansi. Yogyakarta: BPFE.

Himpunan Peraturan Perundang-Undangan. (2013). Pemerintahan Desa dan Kelurahan. Bandung: Fokusmedia.
Mascha, Mashuri. (2013). Politik

Pemerintahan Desa Di Indonesia. Yogyakarta: Polgov.

Putra, Muhammad Mahardi. (2018). Hubungan

Ekonomi Keluarga Dengan Prestasi

Belajar Siswa Kelas XII DI SMAN 5 Pontianak.

Purwanto, Ngalim. (1997). Teknik-Teknik Evaluasi pendidikan. Jakarta: Nasco.

Nopianti. (2015). Pengaruh Status Sosial Ekonomi Keluarga Terhadap Motivasi BelajarSiswa Dalam Pebelajaran Akuntansi Kelas XI di SMA Taman Mulia. Pontianak: Universitas Tanjungpura

Laily, Nur dan Budiyono Pristyadi. (2013). Teori Ekonomi Mikro. Jakarta: Graha Ilmu.

Suherman, Rosyidi. (2011). Pengantar Teori Ekonomi Pendekatan Kepada Teori Ekonomi Mikro dan Makro. Jakarta: Rajwali Pers.

Sukirno, Sadono. (2013). Mikro Ekonomi Teori Pengantar. Jakarta: PT. Raja Grafindo Persada.

Sardiman A.M. (2015). Interaksi dan Motivasi Belajar Mengajar. Jakarta: PT Raja Grafindo Persada.

Purnomo, Sigit. (2008). Ekonomi Umum II. Yogyakarta: BPFE

Sugiono. (2017). Metode Penelitian Kuantitaf Kualitatif dan $R \& D$. Bandung: Alfabeta.

T.Gilarso. (2002). Pendapatan Nasional. Yogyakarta: Kanisius.

Tilaar HR. (20000. Paradigma Baru Pendidikan Nasional. Jakarta: Reneka Cipta

Undang-Undang \& Peraturan Pemerintah RI Tentang Undang-Undang Kepolisian, Hak-Hak Anggota Kepolisian, Gaji Baru TNI \& Kepolosian, Wilayah

Negara RI, UU. Tentara Nasional Indonesia, Pertahanan Negara Kepolisian, Wilayah Negara RI, UU. Tentara Nasional Indonesia, Pertahanan Negara, Kepolisian Negara RI Tahun 2012-2013, 2012, Jakarta : CV Tamita Utama

Undang-Undang Otonomi Daerah Nomor 22 tahun 1999. (1999). pemberian Otonomi Daerah Pemerintah Kabupaten/Kota, Jakarta.

Winardi. (1990). Kamus Ekonomi. Bandung: Mandar Maju. 
(J-PSH) Jurnal Pendidikan Sosiologi Dan Humaniora

Volume 12 Number 1 April 2021

Volume 12 | Number 1| April |2021, Page 42-50/ E-ISSN: 2715-1247 dan P-ISSN: 2087-84xx

Winkel WS. (1994). Psikologi Pengajaran. Jakarta: PT Gramedia.

(http://www.wartamadrasahku.com/2016/04/h

ubungan-ekonomi-keluarga-dengan.html, diakses 12 Juni 2018) 